ORIGINAL ARTICLE / ARTIGO ORIGINAL

Trend in mortality from preventable causes in children: contributions to the evaluation of the performance of public health services in the Southeast Region of Brazil

\title{
Tendência da mortalidade por causas evitáveis na infância: contribuições para a avaliação de desempenho dos serviços públicos de saúde da Região Sudeste do Brasil
}

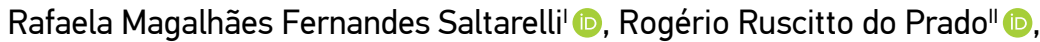 \\ Rosane Aparecida Monteiroll' (D), Deborah Carvalho Malta'v (D)
}

\begin{abstract}
Objective: The aim of this study was to analyze the trend in mortality of children under 5 years old living in the Southeast Region of Brazil and states using the "Brazilian List of Causes of Preventable Deaths". Method: We conducted an ecological time-series study of mortality from preventable and nonpreventable causes, with corrections for ill-defined causes and underreporting of deaths, from 2000 to 2013. Results: There was a decline in the rate of childhood mortality due to preventable (4.4\% per year) and nonpreventable ( $1.9 \%$ per year) causes in the Southeast Region and its states, except for those reducible by vaccine prevention, which remained stable in the period. The study called attention to the smaller decrease in causes of preventable deaths by providing adequate care to women during pregnancy $(1.7 \%)$, with an increase in mortality rates due to basic causes of death due to maternal conditions affecting the fetus or newborn and stability in disorders related to short-term pregnancy and low birth weight, a fact that possibly occurred due to inadequate quality of prenatal care. Minas Gerais showed the greatest reduction in annual percentage of deaths from preventable causes (5.5\%), compared to other FUs, but it led in mortality rates up to 2010, while Rio de Janeiro led between 2010 and 2013. Conclusion: The decline in childhood mortality was expected in the last decade, due to progress in the response of health care systems, and to improvements in health and determinant social conditions as well. However, the rate is still high compared to other countries, showing that there is still much room for improvement.
\end{abstract}

Keywords: Premature mortality. Child mortality. Cause of death. Evaluation of health services. Unified Health System. Epidemiology.

'Department of Medicine and Nursing, Universidade Federal de Viçosa - Viçosa (MG), Brazil.

"School of Nursing, Universidade Federal de Minas Gerais - Belo Horizonte (MG), Brazil.

"'School of Medicine, Universidade de São Paulo - Ribeirão Preto (SP), Brazil.

IvSchool of Nursing, Universidade Federal de Minas Gerais - Belo Horizonte (MG), Brazil.

Corresponding author: Rafaela Magalhães Fernandes Saltarelli. Department of Medicine and Nursing, Universidade Federal de Viçosa. Avenida Peter Henry Rolfs, s/n., Campus Universitário, sala 415, CEP: 36570-900, Viçosa, MG, Brazil.

E-mail: rafaelamagalhaes@ufv.br

Conflict of interests: nothing to declare - Financial support: Fundação de Amparo à Pesquisa do Estado de Minas Gerais (FAPEMIG), Pesquisador Mineiro (PPM), Process No.. 00095-2016. 
RESUMO: Objetivo: Analisar a tendência da mortalidade de crianças menores de 5 anos, residentes na Região Sudeste e Unidades Federativas (UFs), utilizando-se a "Lista Brasileira de Causas de Mortes Evitáveis". Método: Estudo ecológico de séries temporais da taxa de mortalidade por causas evitáveis e não evitáveis, com correções para causas mal definidas e sub-registro de óbitos informados, no período de 2000 a 2013. Resultados: Houve declínio da taxa de mortalidade na infância por causas evitáveis ( $4,4 \%$ ao ano) e não evitáveis ( $1,9 \%$ ao ano) na Região Sudeste e nas UFs, exceto para aquelas reduzíveis por imunoprevenção, que se mantiveram estáveis no período. O estudo chama a atenção para a menor redução das causas de óbitos reduzíveis por adequada atenção à mulher na gestação $(1,7 \%)$, com aumento das taxas de mortalidade por afecções maternas que afetam o feto e o recém-nascido e a estabilidade nos transtornos relacionados com a gestação de curta duração e peso baixo ao nascer. Minas Gerais apresentou o maior percentual de redução anual dos óbitos por causas evitáveis (5,5\%), comparado às demais UFs; no entanto, liderou as taxas de mortalidade até o ano de 2010 e o Rio de Janeiro, entre 2010 e 2013. Conclusão: O declínio da taxa de mortalidade na infância já era esperado nessa última década, levando a acreditar na evolução da resposta dos sistemas de saúde, além das melhorias nas condições de saúde e determinantes sociais. No entanto, o coeficiente se mantém alto quando comparado ao de outros países, mostrando que ainda há muito a se avançar.

Palavras-chave: Mortalidade prematura. Mortalidade na infância. Causas de morte. Avaliação de serviços de saúde. Sistema Único de Saúde. Epidemiologia.

\section{INTRODUCTION}

Various studies have prompted debates on the concept of avoidable death, as well as the definition of better methods for the classification of causes of avoidable deaths ${ }^{1-7}$. Rutstein et al. ${ }^{1}$ are considered pioneers in research on this theme, proposing that preventable deaths are those that could have been prevented (in whole or in part) by the presence of effective health services ${ }^{1}$.

Based on these initial studies, several lists of preventability were proposed in developed countries $^{1-5}$, but modifications and adaptations were necessary in view of different regional, economic, social, epidemiological and technological advances in the health area. It is worth highlighting the review by Nolte and McKee $(2004)^{5}$ on the classifications of preventable causes based on the evolution of the studies on the subject in the 1980s and 1990s, which included dimensions related to the process of economic and social development, as well as scientific knowledge in health that is consolidated and accessible to the public.

There is a consensus that the health sector can decisively influence the decline in mortality from preventable causes ${ }^{1-5}$. Thus, an indicator that considers the concept of avoidable death is a sensitive and useful tool in the evaluation of health systems ${ }^{5.7 .8}$. International and national scientific publications on the preventability of causes of death, including review articles $^{5,8,9}$, evaluation of health service performance ${ }^{10,11}$ and studies of mortality trends in specific groups are growing ${ }^{11-14}$.

They are considered preventable events by available health services: cases of diseases, disabilities, hospitalizations or deaths ${ }^{1}$. The Mortality Information System (SIM) was 
created in Brazil by the Ministry of Health in 1976 with the objective of compiling data on deaths occurring in the country and allowing the construction of demographic and health indicators ${ }^{15,16}$. Despite the improvements in information coverage and quality ${ }^{8}$, there is still a precariousness of data in some municipalities, especially in the North and Northeast regions ${ }^{16}$.

These information gaps in the poorest municipalities reveal the enormous inequalities in health among the Brazilian people, reflecting the lack of access to public goods and services ${ }^{8}$. Considering these limitations, some strategies have been tried to improve these estimates, such as the active search for deaths ${ }^{16}$ and the investigation of ill-defined causes $^{14,15,17}$.

In Brazil, the first review study by Malta and Duarte ${ }^{8}$ was followed in the same year by the proposal of the "Brazilian List of Causes of Preventable Deaths" , referring to the lists of Ortiz ${ }^{6}$ and Tobias and Jackson ${ }^{4}$. This list was developed from the perspective of the technology available in the Unified Health System (SUS), for the following age groups: under 5 years and from 5 to 74 years ${ }^{7}$, where it was revised in $2010^{18}$ and $2011^{19}$.

Brazilian studies have indicated a significant reduction in deaths due to preventable causes in the country and have reinforced the importance of further analyses of the differentials of mortality rates due to preventable causes according to age groups, regions and municipalities in Brazil ${ }^{10,11,13,14}$.

There is a gap in regionalized studies, especially in the Southeast Region, which in 2013 had the highest number of reported deaths from preventable causes in different age groups ${ }^{20}$. The objective of this study was to analyze the mortality trend for the age group of children 0 to 4 years old, residing in the Southeast Region and Federative Units (FUs), according to preventability criteria, using the Brazilian List of Causes of Preventable Deaths ${ }^{7,18}$.

\section{METHOD}

We conducted an ecological time-series study on the trend of the mortality rate in children under five years of age, in the Southeast Region of Brazil, from 2000 to 2013. We used data on deaths and births from SIM and the System of Information on Live Births (SINASC) of the Secretariat of Health Surveillance of the Ministry of Health (SVS/MS).

For the classification of causes of death, the codes of the 10th International Statistical Classification of Diseases and Related Health Problems (ICD-10) were grouped into two groups (preventable and non-preventable) according to the criteria adopted in the Brazilian List of Causes of Preventable Deaths for the population aged 0 to 4 years ${ }^{7,18}$. An adaptation was adopted in the list published in $2010^{18}$, since the original list provided for ill-defined causes of death, which were not considered in this study, since redistribution of ill-defined causes was used.

Next, the preventable causes of deaths were divided into six subgroups according to the type of health intervention based on the technology available in SUS:

- reducible through immunoprevention measures (subgroup 1); 
- reducible through adequate care for woman during pregnancy (subgroup 2);

- reducible through adequate care for woman during delivery (subgroup 3);

- reducible through adequate care for fetus and newborn (subgroup 4);

- reducible through adequate measures of diagnosis and treatment (subgroup 5);

- reducible through adequate health promotion measures (subgroup 6).

The analysis of the data was carried out in two steps:

1. preparation of databases, including:

- redistribution of deaths classified as ill-defined causes;

- correction of underreported deaths;

2. analysis of the trend by applying the Brazilian List of Causes of Preventable Deaths.

The preparation of the database has been necessary, since despite the improvement in the quality of SIM data in recent years, there are still problems regarding under-reporting and non-specific reporting, such as ill-defined causes. Thus, to reduce these problems, new methods for correction of mortality data were incorporated into the study.

Thus, the final mortality rate resulted from the rectification of the crude mortality rate (deaths reported to SIM) using the method for the correction of unreported deaths recommended by the study "Active search for deaths and births in the Northeast and in the Legal Amazon: estimation of SIM and SINASC coverage in Brazilian municipalities" ${ }^{\prime 16}$. In addition, we also performed the correction of the ill-defined causes using the proportional distribution method for the causes defined by Duncan et al. ${ }^{14}$. However, there was an adaptation to this method, since external causes were included in the redistribution of the ill-defined causes. The specific rate of this age group was used without standardization.

For the analysis of the trend of preventable causes and their subgroups and non-preventable causes, the simple linear regression method was performed. Residual analysis was used to evaluate the adequacy of the model, as well as the homoscedasticity of the variables by state and cause (there was no trend in results). The software used was SPSS Statistics, version 17. The statistical significance level was set at $\mathrm{p}<0.05$.

The study showed no ethical implications by using secondary and grouped data, available on the official website of the Ministry of Health, which does not contain information that can identify individuals.

\section{RESULTS}

In the year 2013, 51,344 deaths were reported in Brazil, for all causes, in children under 5 years old, of which 16,612 (32.96\%) occurred in the Southeast Region. The number of deaths from preventable causes in this region declined in the period from 2000 to 2013, from 22,563 deaths in 2000 to 11,117 in 2013 , with a mean percentage decrease in mortality rate of $4.4 \%$ per year (Table 1 ). 
Table 1 presents the absolute number of death cases and the mortality rate per 1,000 live births (LB), corrected for underreporting and ill-defined causes, for each group of preventable causes in the $0-4$ age group, in the period from 2000 to 2013. In addition to these data, the mortality rates for the main basic causes of death specific to each group of preventable diseases and the mean annual percent change in the period analyzed are also shown.

The reducible causes through immunoprevention measures remained stable in the period, with 38 deaths in 2000 and 49 deaths in 2013 ( $\mathrm{p}=0.131)$, but deaths from pertussis showed increased rates from 0.005 (2000) to 0.038 (2013) ( $\mathrm{p}=0.003$ ) (Table 1). In absolute numbers of deaths, this increase meant 7 deaths from pertussis in 2000 to 44 deaths in 2013. Of the 159 deaths from pertussis seen in the period of 2000 to 2013 , most children were male (82), white (84), aged between 28 and 364 days (148) and died in the hospital (157).

The group of causes reducible through adequate care for women during pregnancy showed the highest proportion of deaths among all groups in 2013 (4,367 deaths). Between 2000 and 2013, there was a decrease from 4.7 to 3.7 per 1,000 LB ( $p<0.001$ ), with a mean annual decline of $1.7 \%$. The main specific causes of death in this group were the following:

- respiratory distress syndrome of the newborn showed a percentage decrease of $6.9 \%$ per year $(\mathrm{p}<0.001)$;

- disorders related to short-term pregnancy and low birth weight did not show a change in the period ( $\mathrm{p}=0.215)$;

- causes of death due to maternal conditions affecting the fetus or newborn showed an increase in mortality of $10.9 \%$ per year $(\mathrm{p}<0.001)$, going from $0.27(2000)$ to 0.78 (2013) per 1,000 LB in the period studied (Table 1).

Preventable deaths through adequate care for the woman at delivery showed a decreased mortality rate of $4.5 \%(\mathrm{p}<0.001)$ between 2000 and 2013 . The specific causes of death that contributed most to this group were:

- intrauterine hypoxia and asphyxia at birth, with a decrease of $5.3 \%$ per year $(\mathrm{p}<0.001)$;

- neonatal aspiration syndrome (except due to regurgitated milk and food), with a reduction of $6.6 \%$ per year $(\mathrm{p}<0,001)$;

- fetus and newborn affected by placenta previa and placental abruption and bleeding, with an increase of $0.2 \%$ per year, but not statistically significant $(p>0.183$ ) (Table 1).

The group of causes reducible through adequate care for newborn showed a decline in mortality rate of $5.9 \%$, going from 5 in 2000 to 2.2 in 2013 per 1,000 LB (p $<0.001$ ), taking second place in magnitude, and the causes were as follows:

1. specific respiratory disorders in the neonatal period of the group of specific causes that decreased the most $(10.7 \%)(p<0.001)$; 
2. specific infections in the neonatal period, except congenital rubella syndrome and congenital viral hepatitis, made up the second group of specific causes with greater reduction $(2.8 \%)(\mathrm{p}<0.001)$;

3. other perinatal disorders showed stability in the study period $(\mathrm{p}=0.118)$ (Table 1$)$.

The adequate measures of diagnosis and treatment were responsible for a reduction in deaths from 4,057 to 1,608 between 2000 and 2013 ( $p<0.001$ ). The three main causes of death in this group were the following:

1. pneumonia, with a $6.4 \%$ decrease in mean mortality per year $(\mathrm{p}<0.001)$;

2. other bacterial infections, with a $6.1 \%$ decrease in mean mortality per year $(\mathrm{p}<0.001)$;

1. other acute infections of the lower airways, which displayed stability $(\mathrm{p}=0.189)$ (Table 1).

The mortality rate for causes reducible through adequate health promotion measures was 2.1 deaths in 2000, 1.4 in 2007 and 1.1 in 2013, per 1,000 LB, with a mean annual decrease of $4.3 \%(\mathrm{p}<0.001)$, and these causes were the following:

1. intestinal infectious diseases showed a reduction of $12 \%$ per year in specific mortality rate $(\mathrm{p}<0.001)$;

2. transport accidents fell by $1.7 \%$;

3. other accidental risks to breathing showed stability $(\mathrm{p}=0.148)$ (Table 1$)$.

Figure 1 illustrates the decline in the mortality rate from preventable and non-preventable causes for children under five in the Southeast Region from 2000 to 2013. Preventable causes declined by $4.4 \%$ per year, or $44.3 \%$ in the period ( $\mathrm{p}<0.001$ ), whereas the non-preventable causes fell by $1.9 \%$ per year, or $22 \%$ in the period ( $p<0.001$ ), that is, by half. Regarding the interaction, the rate of preventable causes is related to the non-preventable rate ( $\mathrm{p}$ interaction $<0.001)$. At each reduction in the non-preventable rate of 1 per $1,000 \mathrm{LB}$ there was a reduction of 0.45 per $1,000 \mathrm{LB}$ in the preventable rate.

Table 2 shows the mortality rate from preventable and non-preventable causes according to state in the Southeast Region, which in general followed the same pattern: preventable causes decreased twice as much as non-preventable ones. With regard to preventable causes, the reduction rate was $4.4 \%$ in the period studied, from 17.1 in 2000 to 9.5 in 2013 deaths per $1,000 \mathrm{LB}$. The greatest mean annual reduction in the period was observed in Minas Gerais (5.4\%), followed by Espírito Santo (4.0\%), Rio de Janeiro (3.9\%) and São Paulo (3.8\%).

The percentage reduction in mortality from non-preventable causes was lower (1.9\%) in the period studied, as shown in Figure 1, whereas higher in Espírito Santo (2.4\%), followed by Rio de Janeiro (2\%), São Paulo (1.7\%) and Minas Gerais (1.5\%) (Table 2).

Residual analysis and the evaluation of homoscedasticity by states and causes showed a good fit of the simple linear regression model. The trend in mortality from preventable causes was linear among children under five years of age, which showed a reduction in all groups, except for that of causes reducible by immunoprevention, which remained unchanged in the period. There was no difference in the trend between 2000 and 2007 and between 2007 and 2013 (data not shown). 
Table 1. Absolute number of deaths and corrected mortality rate per 1,000 live births, in children 0 to 4 years old, according to preventable causes and main basic causes specified as preventable by the Brazilian United Health System. Southeast Region, 2000, 2007 and 2013.

\begin{tabular}{|c|c|c|c|c|c|}
\hline Causes & 2000 & 2007 & 2013 & $\begin{array}{l}\% \text { annual } \\
\text { variation }\end{array}$ & p-value \\
\hline \multirow{2}{*}{1 Preventable causes } & 22,563 & 13,676 & 11.117 & & \\
\hline & 17.1 & 11.9 & 9.5 & 4.4 & $<0.00$ \\
\hline \multirow{2}{*}{1.1 Immunoprevention measures } & 38 & 17 & 49 & & \\
\hline & 0.03 & 0.02 & 0.04 & -15.2 & 0.13 \\
\hline Pertussis & 0.005 & 0.004 & 0.038 & -30.5 & 0.003 \\
\hline \multirow{2}{*}{ 1.2 Adequate care for mother during pregnancy } & 6,233 & 4,529 & 4,367 & & \\
\hline & 4.7 & 4.0 & 3.7 & 1.7 & $<0.00$ \\
\hline Newborn respiratory distress syndrome & 2.3 & 1.4 & 0.9 & 6.9 & $<0.00$ \\
\hline $\begin{array}{l}\text { Fetus and newborn affected by maternal } \\
\text { conditions }\end{array}$ & 0.3 & 0.4 & 0.8 & -10.9 & $<0.00$ \\
\hline Short-term pregnancy complications & 0.9 & 1.1 & 0.7 & 1.6 & 0.22 \\
\hline \multirow{2}{*}{ 1.3 Adequate care for mother during delivery } & 2,755 & 1,808 & 1,302 & & \\
\hline & 2.1 & 1.6 & 1.1 & 4.5 & $<0.00$ \\
\hline Intrauterine hypoxia and asphyxia at birth & 1.1 & 0.8 & 0.5 & 5.3 & $<0.00$ \\
\hline Neonatal aspiration syndrome & 0.5 & 0.4 & 0.2 & 6.6 & $<0.00$ \\
\hline Fetus and newborn affected by placenta previa & 0.3 & 0.2 & 0.2 & 0.2 & 0.18 \\
\hline \multirow{2}{*}{ 1.4 Adequate care for newborn } & 6,641 & 3,705 & 2,559 & & \\
\hline & 5.0 & 3.2 & 2.2 & 5.9 & $<0.00$ \\
\hline Specific infections during neonatal period & 1.9 & 1.9 & 1.2 & 2.8 & $<0.00$ \\
\hline Respiratory disorders during the neonatal period & 2.7 & 0.8 & 0.5 & 10.7 & $<0.00$ \\
\hline Other disorders originating in the perinatal period & 0.1 & 0.2 & 0.2 & -1.7 & 0.12 \\
\hline \multirow{2}{*}{ 1.5 Diagnostic measures and adequate treatment } & 4,057 & 2,070 & 1,608 & & \\
\hline & 3.1 & 1.8 & 1.4 & 6.0 & $<0.00$ \\
\hline Pneumonia & 1.5 & 0.8 & 0.6 & 6.4 & $<0.00$ \\
\hline Other bacterial infections & 0.8 & 0.5 & 0.3 & 6.1 & $<0.00$ \\
\hline Other acute infections of lower airways & 0.1 & 0.1 & 0.1 & -1.9 & 0.19 \\
\hline \multirow{2}{*}{ 1.6 Health Promotion measures } & 2,840 & 1,547 & 1,232 & & \\
\hline & 2.1 & 1.4 & 1.1 & 4.3 & $<0.00$ \\
\hline Intestinal infectious diseases & 0.7 & 0.2 & 0.1 & 12.0 & $<0.00$ \\
\hline Other accidental risks to breathing & 0.3 & 0.2 & 0.3 & -1.8 & 0.15 \\
\hline Transport accidents & 0.2 & 0.2 & 0.1 & 1.7 & 0.00 \\
\hline
\end{tabular}


Figure 2 shows the evolution of mortality by UF in the Southeast Region, during the period from 2000 to 2013, for children under five, according to a group of preventable causes. There was a decline in mortality rate in the period studied in all groups except for causes

Table 2. Corrected mortality rate and mean percent of annual reduction per 1,000 live births, in children 0 to 4 years old, according to preventable and non-preventable causes. Southeast Region and its states; 2000, 2007 and 2013.

\begin{tabular}{|c|c|c|c|c|c|c|}
\hline & State & 2000 & 2007 & 2013 & $\begin{array}{l}\% \text { annual } \\
\text { reduction }\end{array}$ & p-value \\
\hline \multirow{5}{*}{ Non-preventable causes } & MG & 6.7 & 6.4 & 5.3 & 1.5 & $<0.00$ \\
\hline & ES & 5.9 & 5.3 & 4.2 & 2.4 & $<0.00$ \\
\hline & RJ & 6.2 & 5.3 & 4.7 & 2.0 & $<0.00$ \\
\hline & $\mathrm{SP}$ & 5.6 & 4.7 & 4.5 & 1.7 & $<0.00$ \\
\hline & Southeast & 6.0 & 5.3 & 4.7 & 1.9 & $<0.00$ \\
\hline \multirow{5}{*}{ Preventable causes } & MG & 22.7 & 14.7 & 10.9 & 5.4 & $<0.00$ \\
\hline & ES & 15.1 & 12.0 & 8.7 & 4.0 & $<0.00$ \\
\hline & RJ & 17.2 & 12.4 & 10.3 & 3.9 & $<0.00$ \\
\hline & $\mathrm{SP}$ & 14.4 & 10.5 & 8.7 & 3.8 & $<0.00$ \\
\hline & Southeast & 17.0 & 11.9 & 9.5 & 4.4 & $<0.00$ \\
\hline
\end{tabular}

UF: unidade federativa.

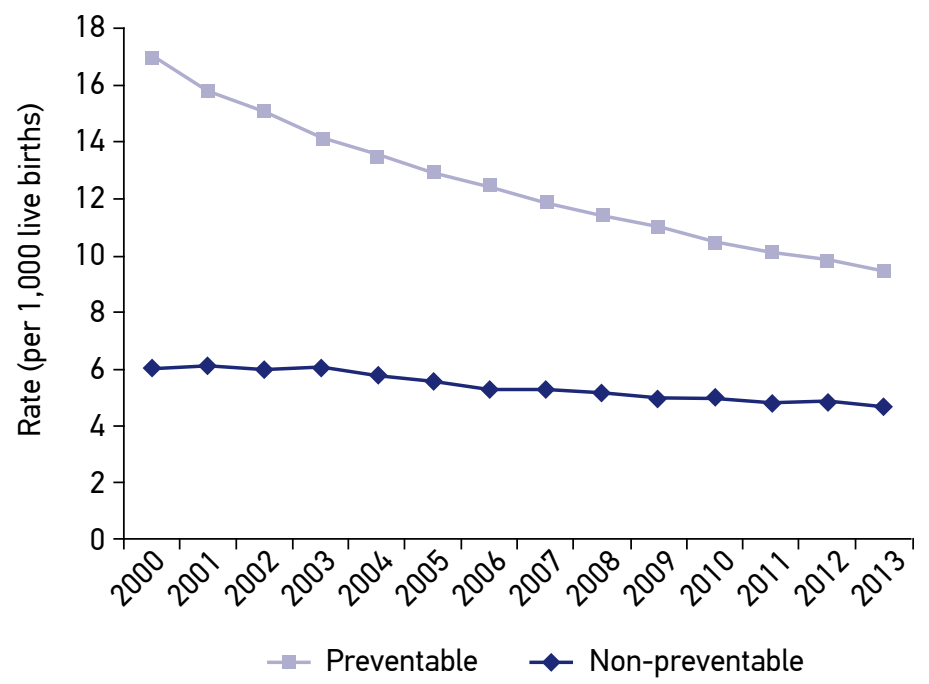

Figure 1. Corrected mortality rate per 1,000 live births, in children 0 to 4 years old, according to preventable and non-preventable causes. Southeast Region, Brazil, 2000 to 2013. 
reducible through immunoprevention actions in the states of Minas Gerais and São Paulo (Figure 2A). Notably, there was a decrease in causes of death reducible through adequate care of women during pregnancy, with stability during the period in Rio de Janeiro (4.6 to 4 per 1,000 LB), followed by São Paulo (4 to 3.4 per 1,000 LB) and Espírito Santo (4.3 to 3.7 per 1,000 with small declines, while in Minas Gerais, there was a substantial decline (6.4 to 4.3 per $1,000 \mathrm{LB}$ ) (Figure $2 \mathrm{~B}$ ).

The other groups showed more similar declines for the other causes preventable through: adequate care for the woman during delivery; adequate care for the newborn; adequate measures of diagnosis and treatment; and health-promotion measures (Figure 2C, D and E).

Rate smoothing was performed in Figure 2A to reduce data fluctuation and Figure $2 \mathrm{~F}$ to exclude the outlier value using the moving mean of two sequential values of the series. It was chosen to present Figure 2 without smoothing, since there was no change in the results.

\section{DISCUSSION}

Our study showed a decline in mortality rate for the population aged 0 to 4 years due to preventable causes that was twice as much as for non-preventable causes in the period 2000-2013 in the Southeast Region and in all states, and also a decrease in all groups of preventable causes of death, except for those reducible by immunoprevention, which remained stable in the period and whose occurrence was low.

The results found were consistent with other studies that have reported a trend towards lower rate for both child mortality (under 5 years) ${ }^{12}$ and infant mortality (less than 1 year $)^{11-13}$.

The 2015 Millennium Development Goals (MDG) Report, produced by the United Nations (UN), showed that child mortality in the world fell by more than half between 1990 and 2015 and that the rate has dropped from 90 to 43 deaths per 1,000 $\mathrm{LB}^{21}$. This decline was observed in emerging areas such as Southeast and East Asia and Oceania, but the most substantial declines were observed in North Africa, Middle East, and Latin America and the Caribbean ${ }^{21}$. Brazil was pointed out ahead of many countries and reached the goal of a $2 / 3$ reduction in child mortality defined by the fourth $\mathrm{MDG}^{21}$.

The reduction of child mortality has been attributed to demographic changes, such as decrease in fertility rate, improvements in health and social conditions, and universal and opportune access to public health services, especially maternal and child health, with expanded coverage of primary health care through the program Family Health Strategy ${ }^{22}$.

The Southeast Region has made substantial progress in reducing child mortality, but since it is the most populous region, it has the highest absolute number of deaths reported in SIM in 2013 (32.96\%), compared to other regions of Brazil. There are very few studies by SUS in the Southeast Region on child mortality due to preventable causes. The present study pointed out the advances, demonstrating positive changes with reduction of preventable deaths by health interventions, in agreement with other studies ${ }^{11-13}$. 
A Reducible through immunoprevention measures

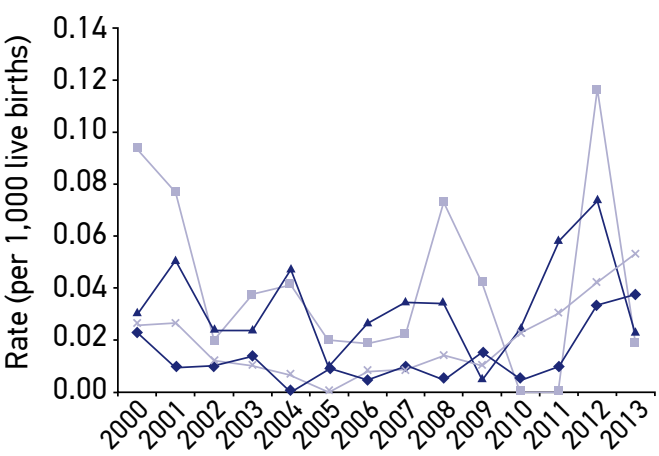

C

Reducible through adequate care for woman during delivery

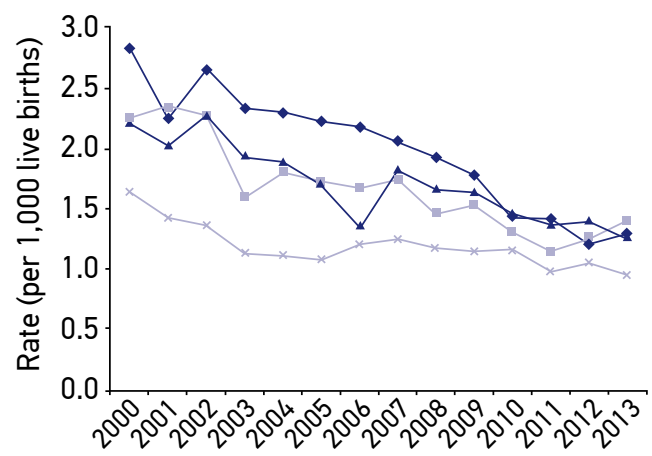

E

Reducible through adequate measures of diagnosis and treatment

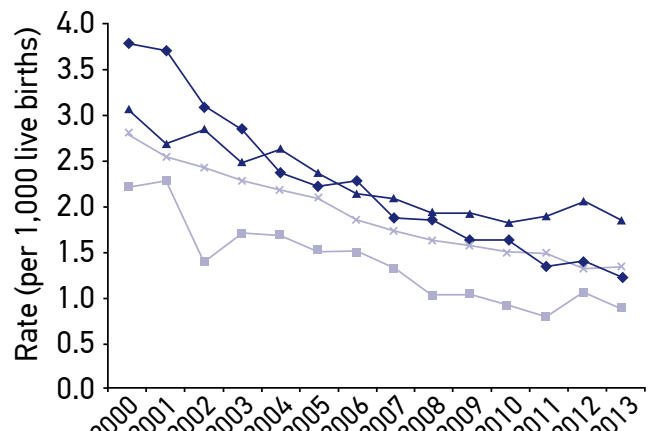

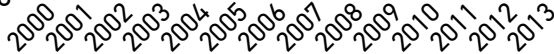

Reducible through adequate care during pregnancy

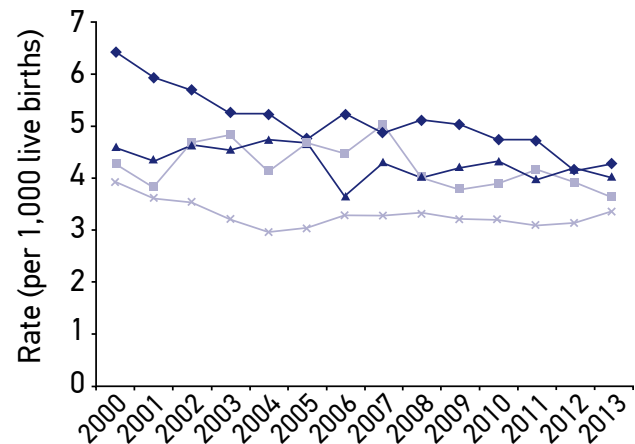

D

Reducible through adequate care for newborn

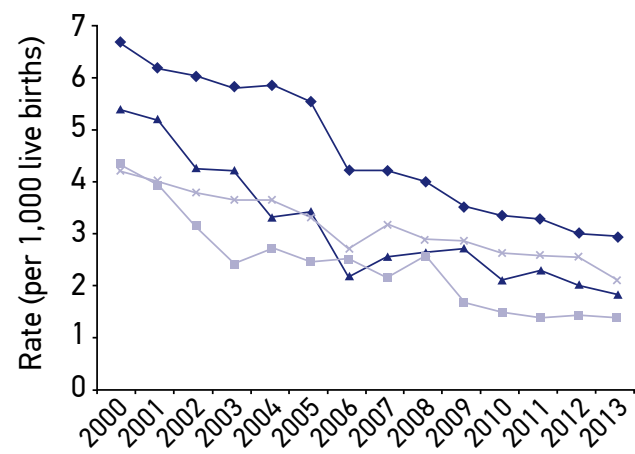

$\mathrm{F}$

Reducible through adequate measures of promoting health

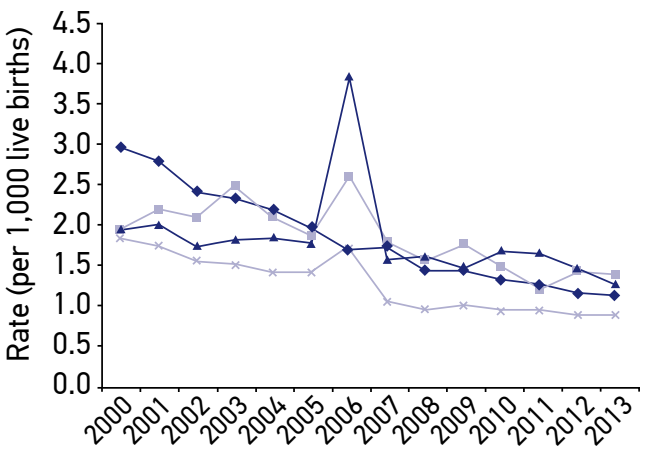

$\rightarrow \mathrm{MG}-\mathrm{ES} \perp \mathrm{RJ} * \mathrm{SP}$

Figure 2. Corrected mortality rate per 1,000 live births, in children 0 to 4 years old. States of Southeast Region, 2000 to 2013. 
The first analysis of preventable deaths among children under 1 year old in the period 1996-2006 showed that deaths from preventable causes showed a significant reduction of $37 \%$, as well as ill-defined causes $(75.7 \%)$ and only $2.2 \%$ for non-preventable causes of death, concluding that health services contributed to the reduction of infant mortality ${ }^{11}$. In addition, the results of the rate of mortality from preventable causes according to region in Brazil showed that the greatest reduction occurred in the Southeast Region $(42 \%)^{11}$. Likewise, the current analysis showed that progress has continued, but there has also been a reduction in causes that are non-preventable through health service measures in a more substantial way (22\% in the period $2000-2013)$. Child mortality is sensitive to general improvements in living conditions and not only to the intervention of the health services, which may partly explain the occurrence ${ }^{11,22}$; however, the reduction of preventable deaths doubled in the study period (44.3\%).

This behavior was seen in all states. Minas Gerais showed higher percentages of reduction of preventable rates, while the other states had lower and similar rates. A study carried out in Belo Horizonte (MG) showed a decline in child mortality rate of $18.7 \%$ in the period from 2006 to 2011 and found that this result might have been associated with several factors, such as greater access to care and prevention and health promotion ${ }^{13}$.

The present study identified that deaths that could be prevented by immunization, which evolved greatly in the past, with about $75 \%$ reduction ${ }^{11}$, remained low and stable. Only in the most recent period did the National Immunization Program (PNI) incorporate new vaccines specifically for the population aged 0 to 4 years. The study identified an average annual increase of $30.5 \%$ in pertussis deaths, reinforcing the need to maintain vigilance, immunization and care actions. Deaths due to lack of access to immunization are low, but they are totally avoidable, requiring that all vigilance actions be maintained to promote their reduction and elimination in the future.

Since the 1990s, neonatal mortality has become a growing concern for public health because it is the main component of infant mortality, due to the reduction of post-neonatal mortality ${ }^{9}$. Perinatal causes are of great importance and magnitude in infant mortality, and although more complex, there is much that is invested in their preventability ${ }^{9,23}$. The Brazilian List of Causes of Preventable Deaths points to the relevance of perinatal causes and draws attention to the high proportion of deaths reducible by adequate care for women during pregnancy and delivery and for newborn. Although these subgroups showed a decreasing trend, some causes increased in the period, such as the increase in mortality rates due to the basic causes of deaths due to maternal conditions affecting the fetus and newborn and the stability in disorders of short-term pregnancy and low birth weight, a fact that may have occurred due to the inadequate quality of prenatal care, as has also been pointed out in other studies ${ }^{11,13}$. It is also seen that in this group, there was decrease in causes such as respiratory distress syndrome, since in the study period, there were initiatives such as the use of surfactant, included in the table of special procedures of the SUS by Ordinance No. 139, of November 101997.

Prenatal care was a critical point in the present study, which reveals a contradiction with data from the Ministry of Health, which indicate a high coverage of prenatal 
consultations. Between 2000 and 2010, the proportions of LB with 7 or more prenatal visits were, respectively, 45.8 and $69.6 \%$ in Minas Gerais, 53.5 and $66.1 \%$ in Espírito Santo, 60.9 and $78.2 \%$ in São Paulo and 57.6 and $64.8 \%$ in Rio de Janeiro ${ }^{24}$. Therefore, the quality of prenatal care should be investigated, since access to it is considered for the vast majority of pregnant women.

However, it has already been observed that more privileged socioeconomic groups, those residing in more developed regions with higher levels of schooling and white women, correspond to the population that has seven or more prenatal visits ${ }^{22}$. Thus, the high proportion of access to prenatal care in the Southeast can be explained in part by the greater concentration of people with a health plan ${ }^{25}$ and the greater presence of health institutions in this region ${ }^{26}$. However, the greater use of health services has been accompanied by excessive medical interventions such as caesarean sections, episiotomies and multiple ultrasound examinations $^{22}$. Low weight may also be related to the higher number of cesareans performed, since it is known that there is a higher percentage of cesarean delivery in private services (around $80 \%)^{13,22}$.

A study conducted by Malta et al. identified an increase of $28.3 \%$ in the causes of death related to adequate care for women during pregnancy and revealed the need to improve prenatal care ${ }^{11}$. Another study by Menezes et al. pointed out the important role of prematurity in infant mortality in Belo Horizonte ${ }^{13}$, which corroborates the findings of the present study, pointing to the severity of prenatal causes in the region.

The causes related to childbirth and newborn care showed better results in the period studied, especially the advances in care for the newborn, which was no longer the main cause of preventable death in 2000, to be the second as of 2005. A similar result was found in the study by Malta et al., with a reduction in deaths and mortality rates due to preventable causes regarding adequate care during delivery $(27.7 \%)$ and for the newborn $(42.5 \% \%)^{11}$.

The data indicated that there was an improvement in the care for newborns soon after delivery in all four states, possibly due to increased access to neonatal intensive care, but with a significant increase of $1.7 \%$ in other perinatal disorders that, even with advances, there is a need for continuous monitoring of care offered in nurseries and neonatal intensive care units ${ }^{11}$.

The reduction of deaths in the group of causes reducible by means of diagnostic measures and adequate treatment ( $6 \%$ per year) was also demonstrated, and pneumonia and other bacterial infections constituted the main causes of death in this group. These results suggested improvements in access to health care network services, with increased primary care, which has made early diagnosis and timely home treatment possible, as well as referral to outpatient and hospital care when necessary. Although the states of São Paulo and Rio de Janeiro have a high concentration of health services, their rates are the highest in the Southeast Region.

With regard to reducible deaths from health promotion actions, intestinal infectious diseases showed a significant reduction, while transport accidents showed a smaller reduction. The sharp decline in deaths from intestinal infectious diseases can be explained by improved sanitation conditions in the Southeast Region, oral rehydration therapy, and access to basic 
health care. Despite the advances in the prevention of deaths due to transport accidents and the implementation of national policies for "Reduction of Morbidity and Mortality by Accidents and Violence" (2005) and "Health Promotion" (2006), these causes can still be widely reduced.

The country has improved its information systems in the last decade, adopting various strategies, public actions and analytical techniques to improve vital statistics, reducing underreporting of births and deaths ${ }^{8,14-17}$. Several improvements have been recorded in SIM and SINASC, reducing ill-defined causes to about $5 \%{ }^{15,17}$; however, the use of techniques for underreporting and for the distribution of these causes is necessary and allows internal and external comparison ${ }^{11}$.

Statistical methods for this correction are used on the basis of the behavior of the defined causes reported ${ }^{27}$. More commonly, proportional redistribution according to defined causes is used, considering all of them ${ }^{27}$ or only non-external causes ${ }^{14}$, or the use of investigation of deaths and redistribution according to the investigated deaths ${ }^{17}$.

Within the limits of this study, the use of data from SIM is still subject to unreported events, which makes it necessary to apply underreporting correction and proportional redistribution of ill-defined causes. Even so, there may still be unreported events. The denominator used was the population of LB and not the under-five population of the Brazilian Institute of Geography and Statistics (IBGE), which might have led to small changes in the calculations. In addition, the study proposes a modification in the use of the Brazilian List of Causes of Preventable Deaths, incorporating corrections for underreporting and ill-defined causes. With regard to lists of preventable deaths, they may change over the years in accordance with technological developments.

\section{CONCLUSION}

The Brazilian List of Causes of Preventable Deaths was a breakthrough for analyses of preventable deaths in Brazil, considering that it takes into account the technology available in SUS. Thus, the results of this study may support the review of the list and the improvement in the causes of preventable death.

The decline in the child mortality rate was expected in the last decade, since the studies of previous decades had already shown this, leading to a belief in the progress of the health systems response, in addition to improvements in health conditions and social determinants. The fact that Brazil is achieving the MDG is very important for children's health. For advances in the coming years, we must improve the identification of the current causes of death, to determine the bottlenecks, besides developing regional analyses and by UF.

This study made it possible to determine the mortality rate in the Southeast Region and its states and thereby indicate which areas are intervention priorities and require more investments. Although they showed a declining trend, mortality rates in children under 5 years of age in the Southeast still remain high when compared to other countries, such as Sweden, Japan, Germany, Cuba and the United States, showing that there is still much to be done. 


\section{REFERENCES}

1. Rutstein DD, Berenberg W, Chalmers TC, Child CG, Fishman AP, Perrin EB. Measuring quality of medicalcare - clinical method. New Engl J Med 1976; 294(11): 582-8. https: / / doi.org/10.1056/NEJM197603112941104

2. Charlton JRH, Velez R. Some international comparisons of mortality amenable to medical intervention. Brit Med J 1986; 292(6516): 295-301.

3. Holland WW, Fitzgerald AP, Hildrey SJ, Phillips SJ. Heaven can wait. J Public Health Med 1994; 16(3): 32130. https:/ / doi.org/10.1093/oxfordjournals.pubmed. a042992

4. Tobias M, Jackson G. Avoidable mortality in New Zealand, 1981-97. Aust N Z J Public Health 2001; 25(1): 12-20.

5. Nolte E, Mckee M. Does health care save lives? Avoidable mortality revisited. Londres: Nuffield Trust; 2004.

6. Ortiz LP. Agrupamento das causas evitáveis de morte dos menores de um ano segundo critério de evitabilidade das doenças. São Paulo: Fundação Seade; 2000.

7. Malta DC, Duarte EC, Almeida MF, Dias MAS, Morais Neto OL, Moura L, et al. Lista de causas de mortes evitáveis por intervenções do Sistema Único de Saúde do Brasil. Epidemiol Serv Saúde 2007; 16(4): 233-44. https: / / doi.org/10.5123/S1679-49742007000400002

8. Malta DC, Duarte EC. Causas de mortes evitáveis por ações efetivas dos serviços de saúde: uma revisão da literatura. Ciênc Saúde Coletiva 2007; 12(3): 765-76. http:/ / dx.doi.org/10.1590/S1413-81232007000300027

9. Lansky S, França E, Leal MC. Mortalidade perinatal e evitabilidade: revisão da literatura. Rev Saúde Pública 2002; 36(6): 759-72. http:/ / dx.doi.org/10.1590/ S0034-89102002000700017

10. Abreu DMX, César CC, França EB. Relação entre as causas de morte evitáveis por atenção à saúde e a implementação do Sistema Único de Saúde no Brasil. Rev Panam Salud Publica 2007; 21(5): 282-91.

11. Malta DC, Duarte EC, Escalante JJC, Almeida MF, Sardinha LMV, Macário EM, et al. Mortes evitáveis em menores de um ano, Brasil, 1997 a 2006: contribuições para a avaliação de desempenho do Sistema Único de Saúde. Cad Saúde Pública 2010; 26(3): 481-91. http: / / dx.doi.org/10.1590/S0102-311X2010000300006

12. Rajaratnam JK, Marcus JR, Flaxman AD, Wang H, Levin-Rector A, Dwyer L, et al. Neonatal, postneonatal, childhood, and under-5 mortality for 187 countries, 1970-2010: a systematic analysis of progress towards Millennium Development Goal 4. Lancet 2010; 375(9730): 1988-2008. https:// doi.org/10.1016/ S0140-6736(10)60703-9
13. Menezes ST, Rezende EM, Martins EF, Villela LCM. Classificação das mortes infantis em Belo Horizonte: utilização da lista atualizada de causas de mortes evitáveis por intervenções do Sistema Único de Saúde do Brasil. Rev Bras Saúde Matern Infant 2014; 14(2): 137-45. http://dx.doi.org/10.1590/ S1519-38292014000200003

14. Duncan BB, Stevens A, Iser BPM, Malta DC, Silva GA, Schmidt MI. Mortalidade por doenças crônicas no Brasil: situação em 2009 e tendências de 1991 a 2009. In: Brasil. Ministério da Saúde. Secretaria de Vigilância em Saúde. Saúde Brasil 2010: uma análise da situação de saúde e de evidências selecionadas de impacto de ações de vigilância em saúde. Brasília: Ministério da Saúde; 2011. p. 119-133.

15. Brasil. Ministério da Saúde. Secretaria de Vigilância em Saúde. Departamento de Análise de Situação em Saúde. Saúde Brasil 2013: uma análise da situação de saúde e das doenças transmissíveis relacionadas à pobreza. Brasília: Ministério da Saúde; 2014.

16. Szwarcwald CL, Morais Neto OL, Frias PG, Souza PRB Jr., Escalante JC, Lima RB, et al. Busca ativa de óbitos e nascimentos no Nordeste e na Amazônia Legal: estimação das coberturas do SIM e do SINASC nos municípios brasileiros. In: Brasil. Ministério da Saúde. Secretaria de Vigilância em Saúde. Saúde Brasil 2010: uma análise da situação de saúde e de evidências selecionadas de impacto de ações de vigilância em saúde. Brasília: Ministério da Saúde; 2011. p. 79-98.

17. França E, Teixeira R, Ishitani L, Duncan BB, CortezEscalante JJ, Morais Neto OL, et al. Causas mal definidas de óbito no Brasil: método de redistribuição baseado na investigação do óbito. Rev Saúde Pública 2014; 48(4): 671-81. http://dx.doi.org/10.1590/ S0034-8910.2014048005146

18. Malta DC, Sardinha LMV, Moura L, Lansky S, Leal MC, Szwarcwald CL, et al. Atualização da lista de causas de mortes evitáveis por intervenções do Sistema Único de Saúde do Brasil. Epidemiol Serv Saúde 2010; 19(2): 173-6.

19. Malta DC, França E, Abreu DX, Oliveira H, Monteiro RA, Sardinha LMV, et al. Atualização da lista de causas de mortes evitáveis ( 5 a 74 anos de idade) por intervenções do Sistema Único de Saúde do Brasil. Epidemiol Serv Saúde 2011; 20(3): 409-12. http:// dx.doi.org/10.5123/S1679-49742011000300016

20. Brasil. Ministério da Saúde. Secretária de Vigilância em Saúde. Mortalidade: Brasil [Internet]. 2013 [acessado em 19 nov. 2015]. Disponível em: http: / / tabnet.datasus. gov.br/cgi/tabcgi.exe?obitocorr/cnv/obitocorr.def 
21. Organização das Nações Unidas. Relatório Sobre os Objetivos de Desenvolvimento do Milênio 2015. Nova York: Organização das Nações Unidas; 2015. p.34-52.

22. Victora CG, Aquino EM, Leal MC, Monteiro CA, Barros FC, Szwarcwald CL. Maternal and child health in Brazil: progress and challenges. Lancet 2011; 377(9780): 186376. https: / / doi.org/10.1016/S0140-6736(11)60138-4

23. Fonseca SC, Coutinho ESF. Pesquisa sobre mortalidade perinatal no Brasil: revisão da metodologia e dos resultados. Cad Saúde Pública 2004; 20(Supl. 1): S7-S19.

24. Brasil. Ministério da Saúde. Secretária de Vigilância em Saúde. Sistema de Informações sobre Nascidos Vivos (SINASC). Cobertura de consultas de pré-natal: Brasil [Internet]. 2013 [acessado em 07 dez. 2015]. Disponível em: http: / / tabnet.datasus.gov.br/cgi/ deftohtm.exe?idb2011/f06.d

25. Brasil. Instituto Brasileiro de Geografia e Estatística. Pesquisa Nacional por Amostra de Domicílios (PNAD). Percentual de cobertura de plano de saúde: Brasil [Internet]. 2013 [acessado em 07 abr. 2015]. Disponível em: http: / tabnet.datasus.gov.br/cgi/ tabcgi.exe?pnad2008/pnad.def

26. Brasil. Ministério da Saúde. Cadastro Nacional dos Estabelecimentos de Saúde do Brasil (CNES): Brasil [Internet]. 2013 [acessado em 07 abr. 2015]. Disponível em: http:/ / tabnet.datasus.gov.br/cgi/tabcgi.exe?cnes/ cnv/estabbr.def

27. Soares GP, Brum JD, Oliveira GMM, Klein CH, Silva NAS. Mortalidade por todas as causas e por doenças cardiovasculares em três estados do Brasil, 1980 a 2006. Rev Panam Salud Publica 2010; 28(4): 258-66.

Received on: 01/18/2016

Final version presented on: 06/03/2016

Accepted on: 08/05/2016

Authors' contributions: Rafaela Magalhães Fernandes Saltarelli and Deborah Carvalho Malta: conception and design of the study, analysis and interpretation of the results, writing and approval of the final version of the manuscript. Rogério Ruscitto do Prado: organization of databases, analyses, review of the manuscript for its scientific content and writing of the final version. Rosane Aparecida Monteiro: review of the manuscript for its scientific content and writing of the final version. All authors read and approved the final version of the manuscript and declare to be responsible for all aspects of the manuscript, ensuring its accuracy and integrity. 